\title{
大豆油脱臭留出物中の抗酸化性物質に関する研究
}

\author{
清 野 肇*・渡辺昭一郎*・阿部 芳 郎** \\ * 北里大学衛生学部 (東京都港区白金 5-96-1) \\ ** 慶忘義塾大学工学部（東京都小金井市前原 4-5-11）
}

\section{Studies on the Antioxidative Compounds in the Deodorizer Sludge of Soybean Oil}

\author{
Hajime SeIno*, Shōichirō WAtanabe* and Yoshirō AbE*** \\ * Faculty of Hygienic Science, Kitasato University (Shirogane-5-9-1, Minato-ku, Tokyo) \\ ** Faculty of Engineering, Keio University (Maehara-cho, Koganei-shi, Tokyo)
}

It is advisable to use natural antioxidative substances instead of synthetic antioxidants for foodstuff. In the previous reports the authors dealt that the unsaponifiable matter obtained from the deodorizer sludge of soybean oil had an inhibiting effect against the autoxidation of partially hydrogenated or thermally polymerized whale oils. There are several reports which dealt the presence of antioxidative substances except tocopherols in the sludge unsaponifiable. Some of these substances are assumed to have the structures similar to those of tocopherols. However, their structures and properties have not yet been fully studied because of the difficulty of their isolation.

In this paper, the concentration of these antioxidative substances from the unsaponifiable matter of the deodorizer sludge of soybean oil through silicagel column was investigated. Three antioxidative substances, one of them was new, were isolated from the concentrates by preparative thin layer chromatography. From the results of UV, IR, Mass and NMR spectra of these substances, it was found that these three antioxidative compounds were tocopherol dimers. The A.O.M. stabilities of partially hydrogenated whale oils containing the mixture of these tocopherol dimers or tocopherols were also determined. As a result it was observed that the mixture of tocopherol dimers had a strong inhibiting effect against the autoxidation of partially hydrogenated whale oil, although the potency was rather lower than that of the mixture of tocopherols.

\section{1 緒訔}

最近，合成食品添加物の人体に対する影響が問題とな り, 多くの話題を呼んでいる。抗酸化剤についても，合 成品にかわって，植物油中に存在するトコフェロールな どの天然抗酸化性物質の利用を再検討しなければならな い時期が来ているものと考えられる。

著者らは，さきにトコフェロールなどの抗酸化性物質 を多量に含む大豆油脱臭留出物の利用を目的とした研究 の一環として, 脱臭留出物から得た不ケン化物中の抗酸 化性成分をある程度濃縮し, その濃縮物を種々の加工鯨 油に添加した場合, とくに水素添加鯨油ならびに加熱低 重合鯨油に対していちじるしい抗酸化性を示すこと，ま た，濃縮物中にトコフェロール類似構造を有すると推定 される二種類の抗酸化性成分が存在することを報告し $た^{1,2)}$ 。

脱臭留出物中の成分の抗酸化性については，竹内 $5^{3)}$,

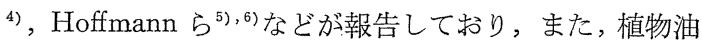
不ケン化物中のトコフェロール類似物質については, た とえば Shone ${ }^{7), 8}$, HcHale ら ${ }^{9)}$, Whittle $ら^{10)}$ および Kováts ${ }^{11)}$ など多くの報告があって,トコフェロールの 酸化生成物あるいはトコフェロール二量体などの存在が 認められている。しかし，これらの物質は存在する量が 少なく, また不安定で単離が困難なため, それらの構造 や性質についてはまだ充分には研究されていないように 思われる。

著者らは，前述のように大豆油脱臭留出物の利用を目 的とした研究を続けているが，本報では，脱臭留出物か ら得た不ケン化物中に存在するトコフェロール類似物質 をシリカゲルカラムによって濃縮し，濃縮物中に，従来 存在を認められていた二種類のトコフェロール類似物質 以外にもら一種類の抗酸化性物質の存在を認めた。さら に, この濃縮物から, 三種類の抗酸化性物質を分取薄層 クロマトグラフィーを繰り返し行なって単離した。つぎ 
に単離されたこれらの物質の UV, IR, 質量スペクトル および NMR スペクトルなどを測定した。その結果, こ れら三種類の抗酸化性物質はいずれもトコフェロール類 の二量体であらうと推定された。ついで,ささにカラム クロマトグラフィーで得られた，これらトコフェロール 二量体類の混合物ならびにトコフェロール類の混合物を 種々の割合で選択水素添加鯨油に添加してその A.O.M. 安定度を測定し, 抗酸化力を比較した。その結果, トコ フェロール二量体の混合物は, トコフェロール類混合物 に比べていくらか劣るが, きわめて高い抗酸化力を有す ることが認められたので以下に報告する。

\section{2 実験および結果}

\section{$2 \cdot 1$ 不ケン化物の抽出}

水分を除いた大豆油脱臭留出物 $920 \mathrm{~g}$ を $1000 \mathrm{ml}$ の エチルエーテルに溶かして分液漏斗にとり，これを $6 \mathrm{~N}-$ 塩酸 $200 \mathrm{~m} l$ ずっで三回洗浄後, 水洗した。さらに $20 \%$ 水酸化カリウム水溶液を水層がフェノールフタレインで アルカリ性を示すまで加えてよく振った後, 水層とエー テル層を分離した。ついで, エーテル層を中性まで水洗 し, 無水硫酸ナトリウムで乾燥した後, エーテルを留去 して中性部分 $320 \mathrm{~g}$ を得た。

つぎに，この中性部分 $75 \mathrm{~g}$ に対して $5 \%$-ピロガロー ル・エタノール溶液 $300 \mathrm{~m} l$ およびエタノール $1,500 \mathrm{~m} l$ を加え, 窒素気流中で加熱した。沸騰しはじめたのち, 60\%-水酸化カリウム水溶液 $75 \mathrm{~m} l$ をすみやかに加光, $2 \mathrm{hr}$ 還流してケン化した。反応終了後, 室温まで冷却 し, 内容物と同容の水を加え, 液々抽出装置を用いてエ チルエーテルで不ケン化物を抽出した。エーテル溶液を 水洗し, 無水硫酸ナトリウムで乾燥後, エーテルを留去 して不ケン化物を得た。この操作を繰り返し，320 g の 中性部分から $127 \mathrm{~g}$ の不ケン化物を得た。

\section{$2 \cdot 2$ 不ケン化物の薄層クロマトグラフィー}

植物油不ケン化物中の成分の薄層クロマトグラフィー による分離に関しては多くの報告 $\left.\left.{ }^{5},(6), 10\right) \sim 15\right)$ があり，いろ いろの溶媒系が用いられている。著者らはこれらの報告 を参考として，各種溶媒系によって不ケン化物の薄層ク ロマトグラフィーを試みた。その結果, トコフェロール 類およびトコフェロール類似物質類の分離には，n一へキ サンーベンゼン混合溶媒系が最も適していると思わ机た。

Fig.-1 に，n-ヘキサンーベンゼンの混合比を $1: 1$ およ び $3: 7$ にした場合の薄層クロマトグラフィーの結果を 示す。図中で， $\alpha, \beta, \gamma, \delta$ の符号をつけたスポットはそ

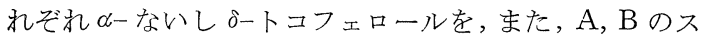
ポットは, トコフェロール類似物質と推定される抗酸化 性を有する未知の成分のスポットである。竹内ら ${ }^{3)}$ はこ れらの抗酸化性を有する新物質を薄層クロマトグラフィ 一などの手段によって分離し，その紫外掠よび赤外線吸
収スペクトルなどを調べ，これらの物質はトコフェロー ル誘導体であるうと推定しているが，著者らは以下にく わしく述べるように, 新抗酸化性成分が Shone ${ }^{7), 8)}$, Whittle ${ }^{10)}$ らにより植物油不ケン化物中に見いだされた トコフェロール二量体に近似の化合物であることを認め た。

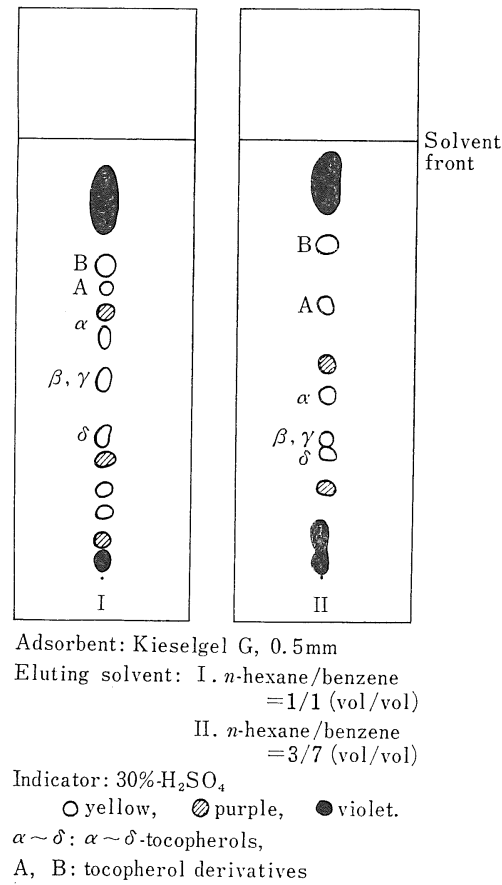

Fig.-1 TLC of unsaponifiable matter.

\section{$2 \cdot 3$ 抗酸化性物質の 濃縮とトコフェロール 誘導体の 単離}

不ケン化物中に存在するトコフェロール類ならびにト コフェロール誘導体類と思われる物質をそれぞれ濃縮す るために以下のような操作を行なった。まず不ケン化物 を 7 倍容の $n$-ヘキサンに溶解し, $0^{\circ} \mathrm{C}$ で $1 \mathrm{hr}$ 保持して 析出するステリンを減圧口別し, 口液部の溶媒を留去し て, カッ色, ペースト状の物質を不ケン化物に対して約 $91 \%$ の割合で得た。つぎに, 内径 $30 \mathrm{~mm}$, 長さ $50 \mathrm{~cm}$ のガラス製カラムに $120^{\circ} \mathrm{C}$ で $3 \mathrm{hr}$ 活性化したカラムク ロマト用シリカゲル $180 \mathrm{~g}$ を充てんし, 上に得られたス テリン類を除いた不ケン化物 $3 \mathrm{~g}$ 安 n一ヘキサン:ベン ゼン $=1: 1(\mathrm{vol} / \mathrm{vol})$ 混合溶媒を用いて, このカラム中 を通過させた。溶出液を $9 \mathrm{~g}$ ずつフラクションコレクタ 一によって捕集し, 各溶出液を薄層クロマトグラフィー で調べて同じ成分を含むものを合わせ，10 個の区分と した。これらの各区分の薄層クロマトグラムを Fig.-2 に示す。この結果, トコフェロール類は区分 6 および区 分 7 によたトコフェロール誘導体類は区分 4 に濃縮さ れていることが認められた。以上の濃縮操作を繰り返 


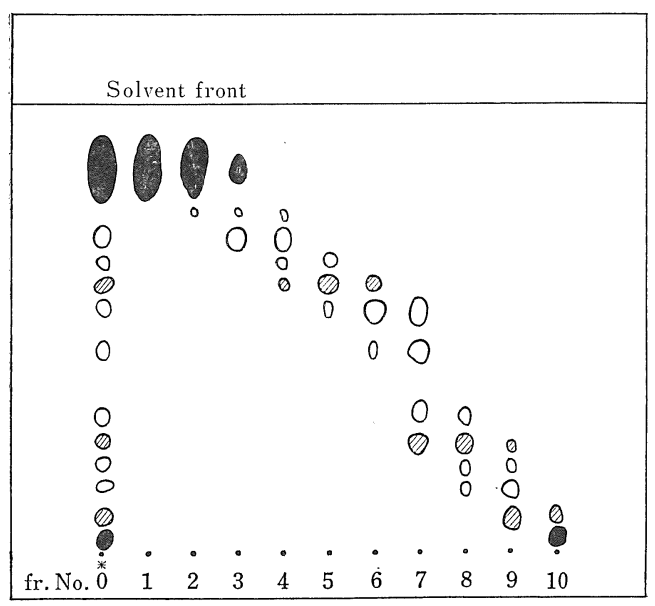

*Unsaponifiable matter

Adsorbent: Kieselgel G, $0.5 \mathrm{~mm}$

Eluting solvent: $n$-hexane/benzene $=1 / 1(\mathrm{vol} / \mathrm{vol})$

Indicator: $30 \% \cdot \mathrm{H}_{2} \mathrm{SO}_{4}$

Fig.-2 TLC of fractions of unsaponifiable matter separated through silicagel column.

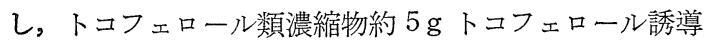
体類濃縮物約 $2.8 \mathrm{~g}$ を得た。両浱縮物とも Fig.-2 に明 らかなようにいくらかの不純物を含んでいる。とくにト コフェロール誘導体類濃縮物中には濃縮前には見られな かったスポットが認められた。この成分は，30\%-硫酸 によってトコフェロール類と同様に淡黄色に呈色し，抗 酸化性を有することが期待された。そこで, 両濃縮物中 の成分の抗酸化性をVioque らの方法 ${ }^{14}$ にしたがい，つ ぎのようにして定性的に確認した。すなわち, 両濃縮物 を薄層プレートにスポットし，Fig.-2 と同様な条件で 展開したのち,プレートにリノール酸を噴霧し, 波長 $365 \mathrm{~m} \mu$ の紫外線を $10 \mathrm{~min}$ 照射して, リノ一ル酸に過 酸化物を発生させた。つぎに，1％-N, $\mathrm{N}^{\prime}$-ジメチルーpフェニレンジアミン塩酸塩ーエタノール溶液をプレート に噴霧して呈色状況を観察した。その結果, Fig.-3 に 示すように, トコフェロール誘導体類濃縮物中に新たに 見られた成分は，トコフェロール類ならびに従来から存 在を認められていた二種類のトコフェロール脬導体と同 様に，紫外線の照射によるリノール酸の過酸化物の生成 を妨げ，抗酸化性を有することが認められた。この物質 もトコフェロール誘導体の一種であるらと推定されたの で，以後トコフェロール誘導体 C と仮称する。

つぎに, トコフェロール誘導体類濃縮物から, 分取薄 層クロマトグラフィーによって, 誘導体 $\mathrm{A}, \mathrm{B}, \mathrm{C}$ の単離 を試みた。厚さ $0.75 \mathrm{~mm}$ の Kieselgel G プレートを用 いて, n-ヘキサン: ベンゼン $=3: 7$ 混合溶媒によって 展開し， A， B，Cをそれぞれかき取り，エチルエーテル で抽出する操作を繰り返して，n-ヘキサンーベンゼン混 合溶媒系の薄層クロマトグラフィーで, それぞれ単一ス

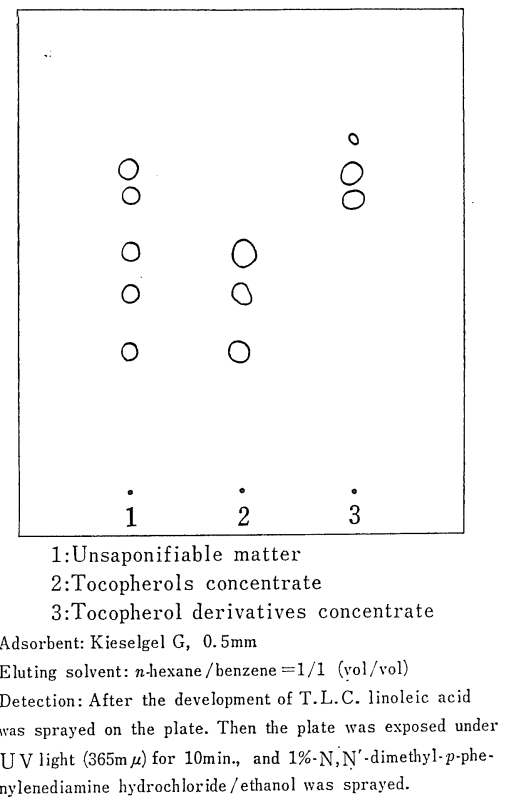

Fig.-3 Detection of antioxidative substances.

ポットを示す物質を得た。これらの物質はいすれも黄色 の粘度の高い液体であった。

\section{4 トコフェロール誘導体類の分析}

$2 \cdot 3$ で単離された三種類のトコフェロール誘導体類の それぞれてついて,エタノール溶液としてUV スペクト ルを測定した結果を Fig.-4 に示す。

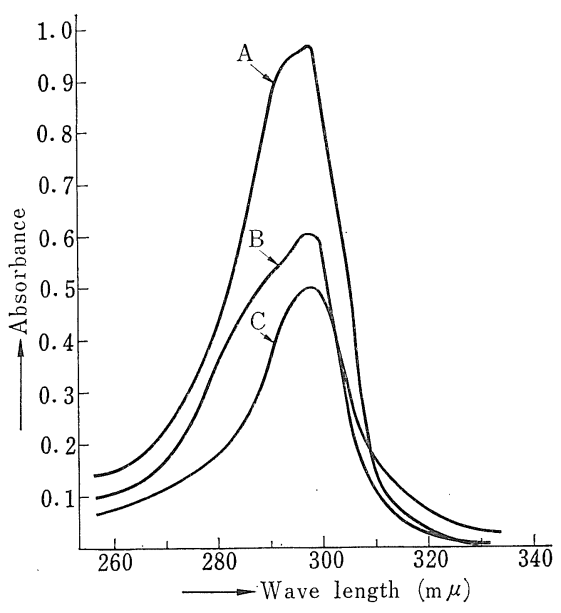

Fig.-4 UV spectra of tocopherol derivatives in ethanol solution.

$\mathrm{A}, \mathrm{B}, \mathrm{C}$ はいずれもトコフェロール類とほぼ同波長の $298 \mathrm{~m} \mu$ 付近に吸収極大を有することが認められた。つ ぎにそそれぞれのIR スペクトルを測定した結果，Fig。一 5 7 に示すように, 波数 $3500 \mathrm{~cm}^{-1}$ 付近の水酸基の吸 収がいずれも小さくなり，かつ高波数側にずれている 


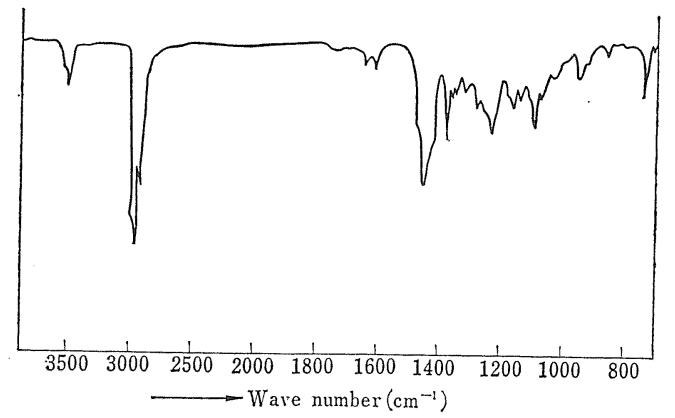

Fig.-5 IR spectrum of tocopherol derivative A.

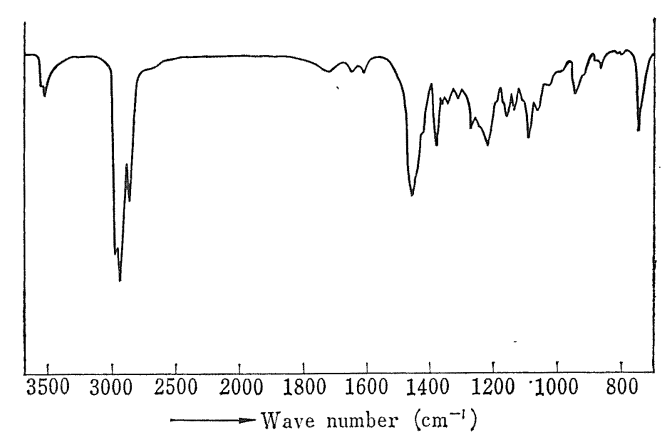

Fig.-6 IR spectrum of tocopherol derivative B.

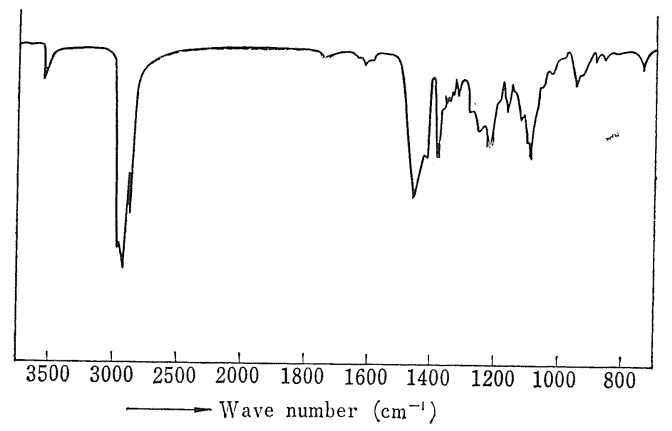

Fig.-7 IR spectrum of tocopherol derivative C.

点，1650 1610 $\mathrm{cm}^{-1}$ にトコフェロールでは認められな かった吸収がある点を除いては，トコフェロール類とほ ぼ似た吸収パターンを示し,さきのUVスペクトルの結 果とあわせて， A， B，C がいずれもトコフェロール類に よく似た構造を有していることが推定された。

つぎに，A，B，Cそれぞれの NMR スペクトルを測定 した結果を Fig.-8 に示す。これらのスペクトルもトコ フェロール類のそれによく似ていたが，2.1〜2.2ppm 付近の芳香環に結合したメチル基のプロトンのシグナル がトコフェロール類のそれよりも複雑に分岐しているの が認められた。またトコフェロールでは $4 \mathrm{ppm}$ 付近の フェノール性水酸基のプロトンのシグナルがAではほと んど認められず，BおよびCでは $4.7 \mathrm{ppm}$ に認められ た。

さらに, これらの物質の質量スペクトルを測定した結
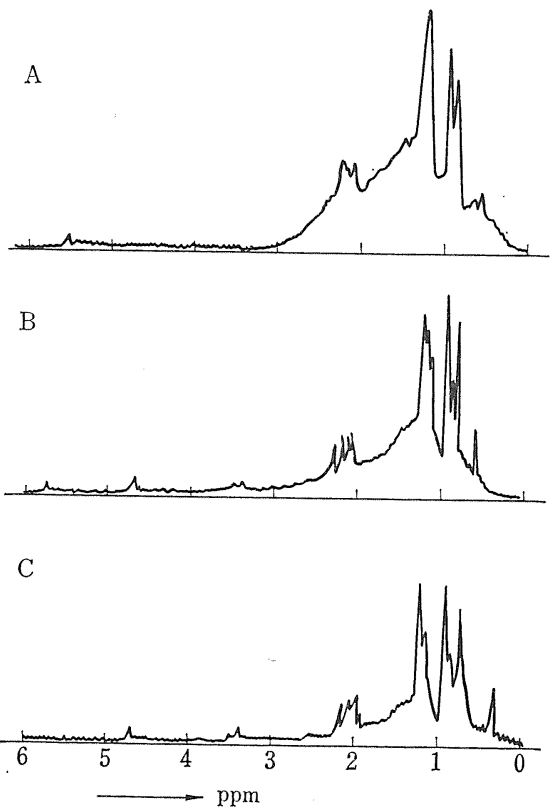

Fig.-8 NMR spectra of tocopherol derivatives.

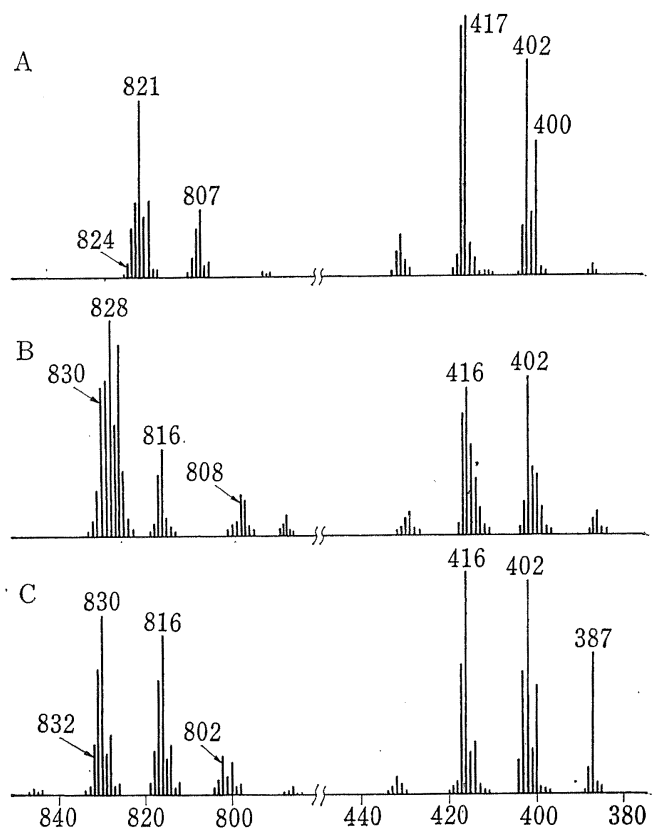

Fig.-9 Mass spectra of tocopherol derivatives.

Table-1 Molecular weights of tocopherol derivatives.

\begin{tabular}{c|c|c|c}
\hline & $\mathrm{A}$ & $\mathrm{B}$ & $\mathrm{C}$ \\
\hline I & 806 & 824 & 818 \\
II & $820 \sim 824$ & $828 \sim 830$ & $830 \sim 832$ \\
\hline
\end{tabular}

I : determined by vapor pressure equilibrium method II : indicated by mass spectra 
果を Fig.-9 に示す。これらの結果より，A では，820 〜 824, B および C では 828〜832 が，これらの物質の 分子量を示すピークであろうと思われる。確認のため, これらの物質を酢酸エチル溶液として，蒸気圧平衡法に よって分子量を測定した結果を質量スペクトルで示され た值とともに，Table-1 に示す。その結果は，いすれも トコフェロール類の分子量の 2 倍に近い 820〜830を示 し，これらの物質はトコフェロールの二量体であろらと 推定される。

\section{$2 \cdot 5$ トコフェロールニ量体の抗酸化力}

$2 \cdot 3$ で得られたトコフェロール類およびトコフェロー ル二量体類の濃縮物から分取薄層クロマトグラフィーに よってできるだけ不純物を除き，それぞれの混合物を得 た。これらの混合物の抗酸化力を比較するために，混合 物を各種の割合で水素添加鯨油に加え，A.O.M. 安定度 を測定した。試料として用いた水素添加鯨油は，Table2 に示すような性質を持つものである。この試料油各 $100 \mathrm{~g}$ にトコフェロール類あるいはトコフェロール二量 体類の混合物をそれぞれ試料油に対して $0.01 〜 0.15 \%$ の割合で加え， $50^{\circ} \mathrm{C}$ の水浴上で 20 30 min，窒素ガス

Table-2 Characteristics of hydrogenated whale oil.

\begin{tabular}{c|c|c|c|c}
\hline A.V. & S.V. & I.V. & $\operatorname{mp}\left({ }^{\circ} \mathrm{C}\right)$ & $\begin{array}{c}\text { A.O.M. } \\
\text { (hr) }\end{array}$ \\
\hline 0.17 & 187.4 & 65.1 & $36 \sim 38$ & 25 \\
\hline
\end{tabular}

Table-3 A.O.M. stabilities of hydrogenated whale oils containing tocopherols or tocopherol dimers.

\begin{tabular}{l|l|l|l|l|l|l}
$\begin{array}{r}\text { Concentra- } \\
\text { tion of } \\
\text { additives } \\
(\%)\end{array}$ & - & 0.01 & 0.03 & 0.05 & 0.10 & 0.15 \\
\hline $\begin{array}{l}\text { Additives } \\
\text { Tocopherols }\end{array}$ & $25 \mathrm{hr}$ & 47 & 90 & 97 & 169 & 252 \\
Tocopherol dimers & 25 & 34 & 59 & 66 & 145 & 195 \\
\hline
\end{tabular}

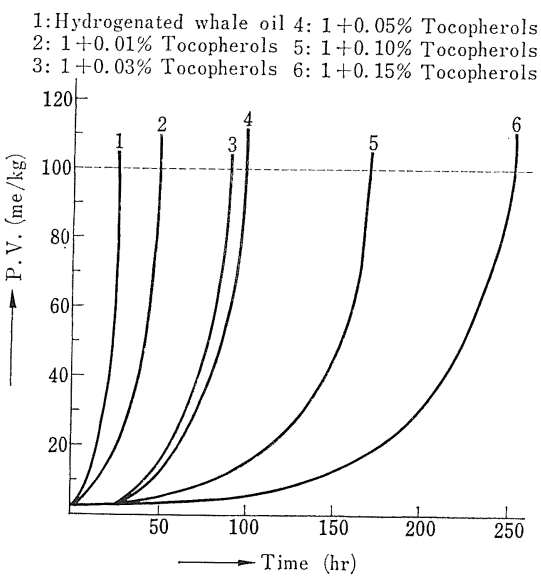

Fig.-10 A.O.M. stabilities of hydrogenated whale oils containing tocopherols.

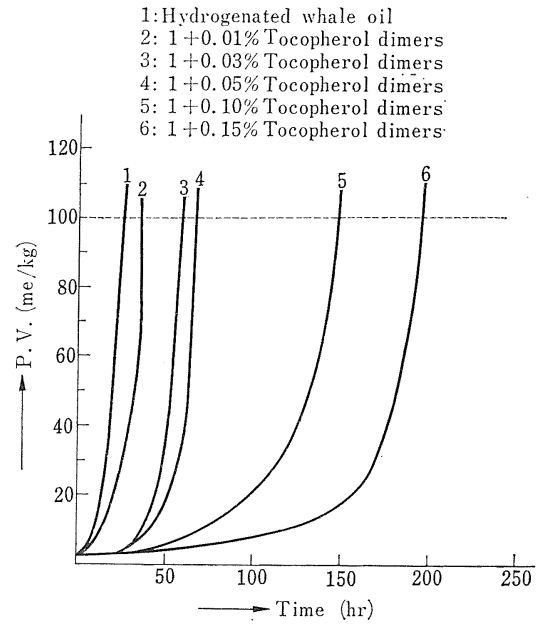

Fig.-11 A.O.M. stabilities of hydrogenated whale oils containing tocopherol dimers.

を通じながらかくはん溶解させたものを安定度測定の試 料とした。これらの各試料について，A.O.C.S. の規 定 $^{15}$ にしたがって A.O.M. 安定度を測定した結果を Table-3 に，また測定中の過酸化物価の変化を Fig.10,11 に示す。

Table-3 および Fig.-10,11に見られるように，大豆 油脱臭留出物不ケン化物から得たトコフェロール二量体 混合物は，水素添加鯨油に対してきわめて高い抗酸化効 果を示し，その効果は添加量が試料油に対して $0.01 \%$ 〜 $0.15 \%$ の範囲では，添加量の増加とともに試料油の A.O.M. 安定度もほぼ直線的に増加し，添加量が 0.15 \%の場合には無添加の試料の約 8 倍の安定度を示す一 方，トコフェロール混合物の場合には，二量体混合物よ りもさらに大きな 抗酸化効果を示し，添加量が $0.15 \%$ の試料油は，無添加の試料の約 10 倍の A.O.M. 安定度 を示した。

\section{3 考察}

著者らが大豆油脱臭留出物の不ケン化物から単離した 三種類の抗酸化性物質は, その分子量などからトコフェ ロールの二量体であろらと推定された。呉地 ${ }^{16), 17) ~}$ BHA をベンゼン溶液中で光により酸化させ, 得られた 生成物を分析した結果, BHA 2 分子間の芳香核水素の 離脱によって生じたジフェニル化合物および 2 分子の $\mathrm{BHA}$ の芳香核水素と水酸基水素の離脱によって生じた エーテル結合をもつ化合物の二種類の二量体が生じてい

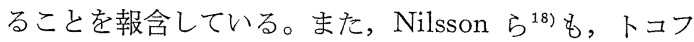
ェロール類およびモデル化合物を酸化重合させて得た生 成物を UV, IR, NMR，質量スペクトルなどで分析した 結果から，トコフェロール類が重合する過程を推定し， それらがジフェニル構造もつ二量体，あるいはエーテル 
( I)

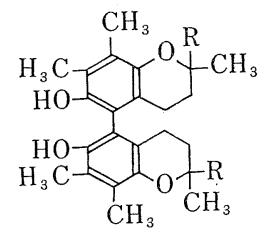

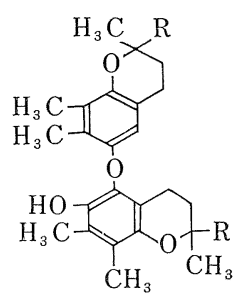

(II)

$$
\text { R: }-\left(\mathrm{CH}_{2}-\mathrm{CH}_{2}-\mathrm{CH}-\mathrm{CH}_{2}\right)_{3} \mathrm{H}
$$

Fig.-12 Dimers of $\gamma$-tocopherol.

わめて高い抗酸化効果を示した。著者らはさきに，大豆 油脱臭留出物の不ケン化物を水素添加鯨油や加熱低重合 結合をもつ二量体などを形成するとしている。著者らの 得た三種類の化合物の分析結果のらち BおよびCのそ れは, Nilsson ら ${ }^{18)}$ がケーもしくは $\delta$ タコフェロールの 二量体としているものの分析結果とよく一致している。 なお， NMR スペクトルで芳香環のメチル基のシグナル がトコフェロールのそれよりも多く分岐しているのは， 二量体の形成により，フリーローテーションが妨害を受 けたためと考えられる。さらに, 分子量測定の結果 Bお よびCは，ケートコフェロールが Fig.-12 に示すような， (I ) ジフェニル構造をもった二量体, あるいは (II) エ 一テル結合をもつ二量体を形成したときの分子量 830 と 一致する值が得られており，B および C がそれらのい ずれかの二量体である可能性がきわめて強い。また， $\mathrm{A}$ もその分子量およびその他の分析結果から，トコフェロ 一ル類の二量体であると思われる。

呉地 ${ }^{17)}$ は BHA の酸化によって生じた二量体が, 抗酸 化能を保有していることを報告しているが，著者らが得 たトコフェロール類の二量体の混合物も，水素添加鯨油
に対してトコフェロール類混合物よりはやや劣るが，き 鯨油に添加して A.O.M. 安定度を測定し，不ケン化物

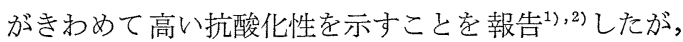
本実験で得たトコフェロール類混合物およびトコフェロ 一ル二量体混合物の場合は，不ケン化物の $1 / 5 \sim 1 / 6$ の 添加量で不ケン化物とほぼ同等の效果を示すことが認め られた。しかし，これらの混合物では，不ケン化物の際 に認められる最適濃度が, 添加量が $0.01 〜 0.15 \%$ の範囲 内では認められなかった。

(昭和 45 年 11 月 20 日受理)

$$
\text { 文献 }
$$

1) 阿部, 清野, 李, 鈴木, 油化学, 15, 94 (1966)

2) 阿部, 清野, 蓮見, 若松, 油化学, 18, 183 (1969)

3) 竹内, 立川, 油化学, 16, 185 (1967)

4) 立川, 竹内, 油化学, 17, 77 (1968)

5) R.L. Hoffmann et al., J. Am. Oil Chemists' Soc., 39, 323 (1962)

6) R.L. Hoffmann et al., J. Am. Oil Chemists' Soc., 41, 116 (1964)

7) G. Shone, Chem. \& Ind., Feb. 23, 335 (1963)

8) G. Shone, J. Sci. Food Agric., 13, 315 (1962)

9) D. McHale, J. Green, Chem. \& Ind., June 15. 982 (1963)

10) K.J. Whittle, J.F. Pennock, Analyst, 92, 423 (1967)

11) L.T. Kováts, E.B. Krasner, Die Nahrung, 11, 671 (1967)

12) A. Seher, Fette-Seifen Anstrichmittel, 60, 1144 (1958)

13) A. Seher, Fette-Seifen Anstrichmittel, 61, 345 (1959)

14) Vioque et al., Grasas y Aceites, 18, 310 (1967)

15) A.O.C.S. Tentative Method Ce $12-57$

16）咫地, 衛生化学, 13, 191 (1967)

17) 呉地, 衛生化学, 15, 301 (1969)

18) J.L.G. Nilson, G.D. Daves, Jr., K. Folkers, Acta Chemica scand., 22, 207 (1968) 